\title{
PEMBERIAN AMELIORAN PUPUK KANDANG AYAM PADA PENGGUNAAN LAHAN GAMBUT YANG BERBEDA TERHADAP EMISI $\mathrm{CO}_{2}$
}

\section{CHICKEN MANURE AMELIORANT APPLICATION IN DIFFERENT

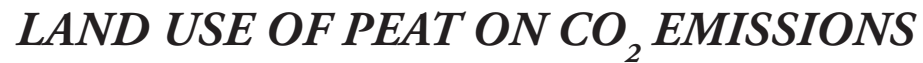

\author{
Terry Ayu Adriany, Ali Pramono dan Prihasto Setyanto ${ }^{1]}$
}

(Diterima tanggal 22-03-2016; Disetujui tanggal 24-08-2016)

\begin{abstract}
ABSTRAK
Rendahnya produktivitas tanah gambut disebabkan oleh tingginya kandungan asam organik dan kemasaman tanah. Pemberian amelioran pupuk kandang ayam dapat meningkatkan produktivitas tanah gambut dan mempengaruhi dinamika emisi $\mathrm{CO}_{2}$. Kegiatan penelitian bertujuan untuk mengetahui pengaruh pemberian pupuk kandang ayam pada tanah gambut yang berasal dari penggunaan lahan yang berbeda terhadap emisi $\mathrm{CO}_{2}$. Penelitian dilakukan ex situ di Laboratorium Gas Rumah Kaca di Balai Penelitian Lingkungan Pertanian. Metode yang digunakan eksperimental dengan menggunakan Rancangan Acak Kelompok (RAK) faktorial, diulang 3 kali. Faktor pertama tanah gambut yang berasal dari penggunaan lahan yang berbeda yaitu tanaman karet semak (L1), karet dengan tanaman sela nanas (L2) dan semak belukar (L3). Faktor kedua dosis amelioran pupuk kandang ayam yaitu $0 \mathrm{t} \mathrm{ha}^{-1}$ (A1) sebagai kontrol dan $4 \mathrm{tha}^{-1}$ (A2). Variabel yang diamati adalah fluks $\mathrm{CO}_{2}$, sifat kimia tanah gambut dan kemasaman tanah. Hasil penelitian menunjukkan pemberian amelioran pupuk kandang ayam pada penggunan lahan gambut yang berbeda tidak memberikan pengaruh nyata terhadap emisi $\mathrm{CO}_{2}$. Penggunaan tanah gambut yang berasal dari penggunaan lahan karet dengan tanaman sela nanas tanpa pemberian amelioran pupuk kandang ayam memberikan pengaruh nyata dalam menurunkan emisi $\mathrm{CO}_{2}$ dengan rata-rata terendah yaitu $1803 \mathrm{~kg} \mathrm{ha}^{-1} \mathrm{th}^{-1}$.
\end{abstract}

Kata kunci : tanah gambut, emisi $\mathrm{CO}_{2}$, bahan amelioran, pupuk kandang ayam

\begin{abstract}
The low peat soil productivity is caused by high content of organic acids and soil acidity. Application of chicken manure ameliorant could increase productivity of peat soil and affect dynamics of $\mathrm{CO}_{2}$ emissions. Research aimed to know effect chicken manure ameliorant applicaton in different land use of peat on $\mathrm{CO}_{2}$ emissions. The Research carried out ex situ in The Greenhouse Gas Laboratory in Indonesian Agricultural Enviroment Research Institute. Method used experimental by Randomized Block Design (RBD) factorial, repeated 3 times. The first factor derived from the peat soil of different land use those were rubber plant with shrubs (L1), rubber and pineapple intercropping plant (L2) and shrubs (L3). The second factor was dose of chicken manure ameliorant those were 0 tha ${ }^{-1}$ (A1) as control and 4 t ha ${ }^{-1}(A 2)$. Variables were observed: fluxs $\mathrm{CO}_{2}$, peat soil chemical properties and soil acidity. The results showed there was no impact of the peat soils from different land use and chicken manure ameliorant on $\mathrm{CO}_{2}$ emissions. The land use with rubber and pineapple intercropping plant without chicken manure ameliorant application significantly influenced to decrease of the $\mathrm{CO}_{2}$ emissions that was equal to $1803 \mathrm{~kg} \mathrm{ha}^{-1} \mathrm{yr}^{-1}$.
\end{abstract}

Keywords : peat soil, $\mathrm{CO}_{2}$ emissions, ameliorant, chicken manure

\section{PENDAHULUAN}

Tanah gambut merupakan jenis tanah yang mengandung bahan organik tinggi dan memiliki kemasaman tanah yang tinggi. Pem- bentukan tanah gambut oleh timbunan bahan sisa tanaman yang berlapis dan membutuhkan proses geogenik yang berlangsung dalam

${ }^{1}$ Balai Penelitian Lingkungan Pertanian, Jl. Jakenan-Jaken Km 5 Jakenan Pati 59182 Jawa Tengah

E-mail: terry_jaa@yahoo.com 
waktu yang sangat lama. Sifat kimia tanah gambut didominasi oleh asam-asam organik yang merupakan suatu hasil akumulasi sisasisa tanaman sehingga memiliki $\mathrm{pH}$ tanah yang rendah, tingkat kesuburan yang rendah, dan miskin unsur hara. Secara fisik tanah gambut bersifat kadar air yang tinggi yaitu 13 kali berat keringnya, bulk density (BD) yang rendah, subsiden (penurunan permukaan), daya menahan beban (bearing capacity) yang rendah dan apabila mengering tidak dapat kembali menyerap air (irreversible drying) [1].

Lahan gambut dalam kondisi alaminya merupakan penyimpan (net sink) karbon yang relatif stabil. Apabila kondisi alami pada lahan gambut terganggu dapat mempercepat proses dekomposisi, sehingga karbon yang tersimpan tersebut teremisi membentuk gas rumah kaca (GRK) terutama $\mathrm{CO}_{2}$. Kegiatan alih fungsi lahan gambut mengakibatkan perubahan pada sifat fisik, kimia dan biologi tanah gambut yang mempunyai ciri khas. Pembukaan lahan gambut untuk aktivitas pertanian yang mengharuskan penurunan tinggi muka air tanah diikuti dengan penambahan pupuk dan amelioran akan meningkatkan oksidasi pada permukaan gambut dan dapat menyebabkan terjadinya peningkatan emisi $\mathrm{CO}_{2}$.

Lahan gambut merupakan salah satu sumber emisi gas rumah kaca terbesar di Indonesia $[2,3,4]$ seiring dengan peningkatan jumlah penduduk, pembukaan hutan, kebakaran hutan gambut serta untuk perluasan lahan pertanian dan perkotaan. Emisi yang berhubungan dengan alih fungsi lahan dan pengelolaan lahan gambut mendekati 50\% dari emisi GRK nasional Indonesia [5]. Emisi $\mathrm{CO}_{2}$ dari proses dekomposisi lahan gambut adalah sebesar 355 Mt $\mathrm{y}^{-1}$ dan $855 \mathrm{Mt} \mathrm{y}^{-1}$ pada tahun 2006, 82\% berasal dari Indonesia dan sebagian besar dari lahan gambut di Sumatera dan Kalimantan [2]. Hasil dekomposisi yang terjadi pada permukaan gambut akibat alih fungsi lahan pada kondisi aerob menghasilkan gas $\mathrm{CO}_{2}$ dan pada zona lebih dalam dengan kondisi anaerob menghasilkan gas $\mathrm{CH}_{4}$. IPCC (Intergovernmental Panel on Climate Change) 2001 [6] melaporkan bahwa kontribusi GRK terhadap pemanasan global seperti karbon dioksida (60\%), metana (20\%) dan nitro oksida (6\%). Konsentrasi $\mathrm{CO}_{2}$ di atmosfir sejak tahun 1980 meningkat sekitar 0,4 \% setiap tahun. Peningkatan konsentrasi $\mathrm{CO}_{2}$ pada tahun 2014 - 2016 sebesar 2-3 ppm per tahun. Konsentrasi $\mathrm{CO}_{2}$ di atmosfir pada bulan Juli tahun 2014 sebesar 399,04 ppm meningkat menjadi 401,31 ppm di tahun 2015 dan meningkat menjadi 404,39 ppm di tahun 2016 [7]. Sedangkan, batas atas konsentrasi $\mathrm{CO}_{2}$ yang aman bagi atmosfir bumi adalah $350 \mathrm{ppm}$.

Usaha yang dilakukan untuk meningkatkan produktivitas dan menurunkan kemasaman tanah dapat dilakukan dengan pemberian amelioran. Amelioran merupakan bahan yang dapat ditambahkan ke dalam tanah sehingga dapat meningkatkan kesuburan tanah melalui perbaikan kondisi fisik dan kimia tanah. Ameliorasi pada tanah gambut diberikan untuk mengatasi tingginya kemasaman tanah, rendahnya kesuburan tanah, serta meningkatkan produktivitas lahan gambut [8]. Pemberian pupuk kandang ayam memberikan pengaruh positif dibandingkan bahan organik lainnya dalam memperbaiki kualitas tanah masam [9]. Pemberian amelioran pupuk kandang ayam selain mampu meningkatkan kesuburan dan 
produktivitas tanah juga dapat menekan emisi gas rumah kaca dari lahan gambut. Hasil penelitian ICCTF (Indonesia Climate Change Trust Fund) di Kalimantan Tengah menyatakan bahwa aplikasi amelioran memberikan dampak positif terhadap penurunan emisi $\mathrm{CO}_{2}$ di lahan gambut yang ditanami karet. Emisi $\mathrm{CO}_{2}$ pada tanah gambut tanpa aplikasi bahan amelioran (kontrol) sebesar $40 \mathrm{tha}^{-1}$ th$^{-}$ , pupuk gambut $\mathrm{T}$ (pugam T) 20,4 $\mathrm{tha}^{-1} \mathrm{th}^{-1}$ turun $49 \%$, pupuk kandang $22 \mathrm{t} \mathrm{ha}^{-1} \mathrm{th}^{-1}$ turun $45 \%$, pupuk gambut $\mathrm{A} 27,2 \mathrm{tha}^{-1} \mathrm{th}^{-1}$ turun $32 \%$ dan tanah mineral 29,2 $\mathrm{t} \mathrm{ha}^{-1} \mathrm{th}^{-1}$ turun hingga $27 \%$ [10]. Tujuan penelitian ini adalah untuk mengetahui pengaruh pemberian amelioran pupuk kandang ayam pada tanah gambut yang berasal dari penggunaan lahan yang berbeda terhadap emisi $\mathrm{CO}_{2}$.

\section{METODE PENELITIAN}

Penelitian ini dilaksanakan ex situ di Laboratorium Balai Penelitian Lingkungan Pertanian pada bulan Mei sampai September 2012. Bahan tanah gambut berasal dari Desa Jabiren, Kecamatan Jabiren Raya, Kabupaten Pulang Pisau, Provinsi Kalimantan Tengah yaitu tanah gambut yang diambil dari penggunaan lahan yang berbeda: karet, karet dengan tanaman sela nanas dan semak belukar. Peralatan yang digunakan untuk mengetahui bulk density (BD) tanah gambut dapat menggunakan bor tanah khusus untuk tanah gambut (bor gambut), kolom tanah PVC pipa sebagai tempat inkubasi tanah gambut dengan ukuran tinggi $30 \mathrm{~cm}$ dan diameter 8 inchi yang dipasangi selang plastik untuk menjaga kadar air sebesar $60 \%$ dari tinggi tabung yaitu setinggi 19,8 cm, amelioran pupuk kandang ayam, termometer, jarum suntik, GC-GHG type $450, \mathrm{pH}$-meter, gelas ukur, kertas tisu, aquades dan penyemprot (sprayer).

Penelitian menggunakan Rancangan Acak Kelompok (RAK) faktorial. Faktor pertama adalah tanah gambut yang berasal dari penggunaan lahan yang berbeda yaitu karet dengan semak (L1), karet dengan tanaman sela nanas (L2) dan semak belukar (L3). Faktor kedua adalah dosis pemberian amelioran pupuk kandang ayam yaitu $0 \mathrm{t}$ ha $^{-1}$ (A1) sebagai kontrol dan $4 \mathrm{t} \mathrm{ha}^{-1}$ (A2). Masing-masing perlakuan diulang sebanyak 3 kali ulangan, sehingga diperoleh 18 unit percobaan. Variabel utama yang diukur yaitu parameter utama emisi gas rumah kaca $\mathrm{CO}_{2}$ yang dihasilkan dan variabel pendukung yaitu derajat kemasaman $(\mathrm{pH})$ dan temperatur pada saat pengambilan sampel GRK. Adapun kombinasi perlakuan dari masing-masing faktor disajikan pada

\section{Pelaksanaan Penelitian}

Penentuan plot dan titik sampel di lapang dilakukan berdasarkan tipe penggunaan lahan gambut di Desa Jabiren Kalimantan Tengah

Tabel 1. Perlakuan penelitian

\begin{tabular}{lll}
\hline No & Kode & Keterangan Perlakuan \\
\hline 1 & L1A1 & Tanah gambut karet semak dan amelioran pupuk kandang ayam $0 \mathrm{t} \mathrm{ha}^{-1}$ \\
2 & L1A2 & Tanah gambut karet semak dan amelioran pupuk kandang ayam $4 \mathrm{t} \mathrm{ha}^{-1}$ \\
3 & L2A1 & Tanah gambut karet dan tanaman sela nanas, amelioran pupuk kandang ayam $0 \mathrm{t} \mathrm{ha}^{-1}$ \\
4 & L2A2 & Tanah gambut karet dan tanaman sela nanas, amelioran pupuk kandang ayam $4 \mathrm{t} \mathrm{ha}^{-1}$ \\
5 & L3A1 & Tanah gambut semak dan amelioran pupuk kandang ayam $0 \mathrm{t} \mathrm{ha}^{-1}$ \\
6 & L3A2 & Tanah gambut semak dan amelioran pupuk kandang ayam $4 \mathrm{t} \mathrm{ha}^{-1}$ \\
\hline
\end{tabular}


yaitu pada lahan gambut yang ditanami tanaman karet, ditanami karet dengan tanaman sela nanas dan lahan gambut yang ditumbuhi semak. Langkah pertama membuat plot seluas 1 ha, kemudian dilakukan pembuatan grid (sub plot) yang berukuran $10 \mathrm{~m}$ x $10 \mathrm{~m}$. Pengambilan contoh tanah dilakukan pada kedalaman 0-60 cm dari permukaan tanah sesuai dengan berbagai tipe penggunaan lahan gambut. Berat total tanah gambut sebanyak \pm 100 kwintal yang ditempatkan ke dalam karung yang dilapisi plastik berukuran $20 \mathrm{~kg}$, diangkut menggunakan truk menuju Balai Penelitian Lingkungan Pertanian (Balingtan) Jawa Tengah.

Berat contoh tanah gambut sesuai kebutuhan tanah berdasarkan hasil analisa bulk density (BD) dan kadar air tanah gambut (Tabel 3) dengan kebutuhan tanah L1, L2 dan L3 per kolom tanah berturut-turut $8,51 \mathrm{~kg}, 9,80 \mathrm{~kg}$ dan 7,63 kg. Tanah gambut dimasukkan ke dalam kolom tanah berdiameter 8 inchi, tinggi $30 \mathrm{~cm}$ dan diberi perlakuan amelioran pupuk kandang ayam dengan dosis $4 \mathrm{t} \mathrm{ha}^{-1}$ (13.59 gram per kolom tanah). Inkubasi tanah gambut dilakukan selama 50 hari.

Pengambilan contoh gas dilakukan dengan metode closed chamber [11] (Gambar 1) setiap 7 hari sekali sampai 50 hari inkubasi pada pukul 06.00-08.00 WIB, menggunakan jarum suntik volume $10 \mathrm{ml}$ pada interval waktu 10 , 20, 30, 40, 50 dan 60 menit setelah dilakukan penyungkupan pada kolom tanah. Variabel utama yang diamati yaitu fluks dan emisi $\mathrm{CO}_{2}$ yang dihasilkan. Variabel pendukung yang diamati yaitu $\mathrm{pH}$ tanah serta temperatur pada saat penyungkupan pengambilan sampel GRK. Pemeliharaan unit percobaan selama masa inkubasi berlangsung yaitu penyiraman

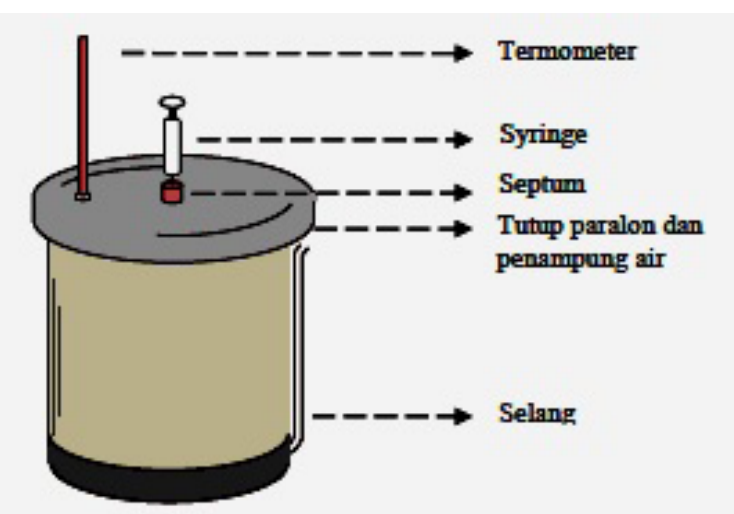

Gambar 1. Gas chamber dan bagiannya

dengan memberikan aquades secara berkala pagi dan sore untuk menjaga kadar air tetap pada ketinggian $60 \%$ dari tinggi kolom tanah (19,8 cm). Parameter lain yang diukur yaitu analisa kandungan bahan organik tanah dan kandungan bahan organik pupuk kandang ayam.

Pengukuran konsentrasi gas $\mathrm{CO}_{2}$ menggunakan peralatan pendukung utama yaitu gas kromatografi GC-GHG Type 450 yang dilengkapi dengan TCD (Thermal Conductivity Detector) untuk menganalisa gas $\mathrm{CO}_{2}$. Hasil analisa contoh gas dapat dihitung menjadi fluks atau emisi dengan menggunakan rumus perhitungan dengan persamaan sebagai berikut [12]:

$$
F=\frac{d c}{d t} \times \frac{V c h}{A c h} \times \frac{m W}{m V} \times \frac{273,2}{(273,2+T)}
$$

Keterangan :

$\begin{array}{ll}\mathrm{F} & : \text { Fluks gas } \mathrm{CO}_{2}\left(\mathrm{mg} \mathrm{m}^{-2} \text { menit }^{-1}\right) \\ \mathrm{dc} / \mathrm{dt}: & : \text { Perbedaan konsentrasi } \mathrm{CO}_{2} \text { per waktu } \\ & \left(\text { ppm menit }{ }^{-1}\right) \\ \mathrm{Vch}: & \text { Volume boks }\left(\mathrm{m}^{3}\right) \\ \mathrm{Ach}: & \text { Luas boks }\left(\mathrm{m}^{2}\right) \\ \mathrm{mW} & : \text { Berat molekul } \mathrm{CO}_{2}(\mathrm{~g}) \\ \mathrm{mV} & : \text { Volume molekul } \mathrm{CO}_{2}(22,411) \\ \mathrm{T} & : \text { Temperatur rata-rata selama pengambilan } \\ & \quad \text { contoh gas }\left({ }^{\circ} \mathrm{C}\right)\end{array}$


Data emisi $\mathrm{CO}_{2}$ dianalisa menggunakan Analysis of Variance (ANOVA) dengan menggunakan uji lanjut Duncan pada tingkat kepercayaan 95\%. Analisis data statistik menggunakan software System Analysis Statistic (SAS) versi 9.1.3.

\section{HASIL DAN PEMBAHASAN}

\section{Fluks dan Emisi $\mathrm{CO}_{2}$}

Hasil pengukuran emisi $\mathrm{CO}_{2}$ yang telah dilakukan selama 50 hari inkubasi pada tanah gambut yang berasal dari penggunaan lahan yang berbeda dan pemberian amelioran pupuk kandang ayam menunjukkan bahwa rata-rata emisi $\mathrm{CO}_{2}$ tertinggi pada perlakuan tanah gambut yang ditanami tanaman karet semak dengan pemberian amelioran pupuk kandang ayam $4 \mathrm{t} \mathrm{ha}^{-1}$ (L1A2) sebesar 2.395 $\mathrm{kg} \mathrm{ha}^{-1}$ tahun $^{-1}$ dan rata-rata emisi $\mathrm{CO}_{2}$ terendah pada perlakuan tanah gambut yang ditanami tanaman karet dan tanaman sela nanas tanpa pemberian amelioran pupuk kandang ayam (L2A1) sebesar $1803 \mathrm{~kg} \mathrm{ha}^{-1}$ tahun $^{-1}$.

Besarnya nilai fluks dan emisi $\mathrm{CO}_{2}$ dari tanah gambut dipengaruhi oleh tipe penggunaan lahan yang dilakukan dalam sistem penerapan budidaya tanaman pertanian. Tingginya emisi $\mathrm{CO}_{2}$ yang dihasilkan dari penggunaan lahan gambut dengan tanaman karet semak (tanaman tahunan dan memiliki kanopi) menyebabkan kelembaban tanah meningkat dan memiliki karbon (C) organik tertinggi, sehingga penambahan bahan organik seperti pupuk kandang ayam dapat meningkatkan jumlah $\mathrm{C}$ organik dan penambahan jumlah mikroba tanah. Hal ini menyebabkan meningkatnya emisi $\mathrm{CO}_{2}$ yang dihasilkan. Berbeda dengan hasil penelitian yang dilakukan dengan tipe tutupan kanopi terbuka pada permukaan tanah di hutan alami memiliki rata-rata fluks $\mathrm{CO}_{2}$ lebih tinggi dibandingkan dengan kanopi tertutup [13].

Hasil penelitian di Kalampangan, Kalimantan Tengah, secara berurutan nilai fluks $\mathrm{CO}_{2}$ yang dihasilkan dari tanah gambut pada beberapa penggunaan lahan adalah gambut hutan alami $>$ semak $>$ jagung $>$ tumpang sari [14]. Peningkatan emisi $\mathrm{CO}_{2}$ tanah gambut terjadi karena perubahan penggunaan lahan dari hutan primer menjadi perkebunan kelapa sawit dan tanaman jagung yang merupakan lahan olahan intensif. Pengolahan intensif menyebabkan agregat tanah menjadi rusak dan bahan organik yang terlindung agregat tanah menjadi terbuka, aerasi dan kelembaban tanah yang tinggi karena suhu meningkat [15]. Hasil penelitian lain menyatakan bahwa emisi $\mathrm{CO}_{2}$ yang dilepas dari penggunaan lahan gambut yang dimanfaatkan untuk tanaman tahunan lebih tinggi dibandingkan lahan gambut yang dimanfaatkan untuk tanaman semusim [16].

Tabel 2. Hasil uji Duncan rata-rata emisi $\mathrm{CO}_{2}$ pada tanah gambut yang berasal dari penggunaan lahan yang berbeda dan Pemberian Amelioran Pupuk kandang Ayam

\begin{tabular}{ccccc}
\hline Pemberian & \multicolumn{2}{c}{ Penggunaan Tanah gambut (kg/ha/th) } & Rata-rata \\
\cline { 2 - 4 } Amelioran & Karet semak (L1) & Karet \& Nanas (L2) & Semak (L3) & Amelioran \\
\hline A1 & $2.363 \mathrm{ab}$ & $1.803 \mathrm{~b}$ & $2.222 \mathrm{ab}$ & $2.129 \mathrm{a}$ \\
A2 & $2.395 \mathrm{a}$ & $1.954 \mathrm{ab}$ & $2.037 \mathrm{ab}$ & $2.128 \mathrm{a}$ \\
Penggunaan Lahan & $2.379 \mathrm{a}$ & $1.878 \mathrm{~b}$ & $2.129 \mathrm{ab}$ & \\
\hline
\end{tabular}

Keterangan : hasil uji Duncan dengan kepercayaan 95\% 
Pengelolaan tanah gambut dengan penanaman tanaman tahunan karet dan tanaman sela nanas menghasilkan emisi $\mathrm{CO}_{2}$ yang lebih rendah yang disebabkan tertutupnya tanah gambut oleh vegetasi (nanas). Adanya tanaman penutup tanah selain mengurangi emisi juga meningkatkan penyerapan karbon, sehingga emisi menjadi lebih rendah.

Pemberian amelioran pupuk kandang ayam (A) pada beberapa tanah gambut yang berasal dari penggunaan lahan yang berbeda (L) tidak memberikan pengaruh nyata $(\mathrm{P}>0.05)$ terhadap emisi $\mathrm{CO}_{2}$ yang dihasilkan. Namun, penggunaan tanah gambut yang berasal dari penggunaan lahan yang berbeda memberikan pengaruh nyata $(\mathrm{P}<0.05)$ terhadap emisi $\mathrm{CO}_{2}$ yang dihasilkan. Penggunaan tanah gambut yang ditanami tanaman karet semak (L1) menghasilkan rata-rata emisi $\mathrm{CO}_{2}$ tertinggi dan pada tanah gambut yang ditanami tanaman karet dan tanaman sela nanas (L2) menghasilkan rata-rata emisi $\mathrm{CO}_{2}$ terendah. Perbedaaan ini disebabkan perbedaan kandungan bahan organik tanah yang terkandung dalam tanah gambut tersebut (Tabel 3). Kandungan bahan organik di dalam tanah berkorelasi positif dengan emisi $\mathrm{CO}_{2}$ yang dihasilkan dari tanah [13]. Semakin tinggi kandungan karbon (C) di dalam tanah maka emisi $\mathrm{CO}_{2}$ yang dihasilkan akan meningkat.

Tanah gambut yang ditanami tanaman karet dan tanaman sela nanas memiliki $\mathrm{C} / \mathrm{N}$ rasio yang lebih rendah yang menyebabkan emisi $\mathrm{CO}_{2}$ yang dilepaskan lebih rendah (Tabel 3). Kandungan $\mathrm{C} / \mathrm{N}$ rasio menunjukkan tingkat dekomposisi bahan organik di dalam tanah. Rasio C/N menandakan besar atau kecilnya karbon yang dapat diakumulasikan, semakin tinggi nilai rasio $\mathrm{C} / \mathrm{N}$ maka akan semakin banyak karbon yang dapat diakumulasikan. Tanah gambut memiliki $\mathrm{C} / \mathrm{N}$ rasio yang tinggi akibat pengelolaan tanah gambut yang menyebabkan aktivitas mikrobiologi tanah dan laju dekomposi meningkat dan menyebabkan teremisinya gas rumah kaca seperti $\mathrm{CO}_{2}$ dan $\mathrm{CH}_{4}$ [8]. Peningkatan $\mathrm{C} / \mathrm{N}$ rasio juga dapat mempercepat proses dekomposisi tanah gambut yang dapat meningkatkan produksi dan emisi $\mathrm{CO}_{2}$ [17].

Hasil pengukuran fluks $\mathrm{CO}_{2}$ harian pada tanah gambut yang berasal dari penggunaan lahan yang berbeda dan pemberian amelioran pupuk kandang ayam disajikan pada Gambar 2. Pemberian amelioran pupuk kandang ayam (A2) pada beberapa tipe penggunaan lahan menyebabkan tingginya fluks $\mathrm{CO}_{2}$ dibandingkan tanpa pemberian pupuk kandang

Tabel 3. Analisa tanah pada tanah gambut yang berasal dari penggunaan lahan yang berbeda

\begin{tabular}{cccc}
\hline Parameter & $\begin{array}{c}\text { Karet semak } \\
(\mathrm{L} 1)\end{array}$ & $\begin{array}{c}\text { Karet dan Nanas } \\
(\mathrm{L} 2)\end{array}$ & Semak (L3) \\
\hline BD & 0,19 & 0,23 & 0,19 \\
C-Organik (\%) & 26,19 & 25,46 & 24,69 \\
N-Total (\%) & 0,52 & 0,69 & 0,31 \\
C/N Rasio & 50,60 & 37,00 & 81,00 \\
$\mathrm{P}_{2} \mathrm{O}_{5}(\%)$ & 0,02 & 0,02 & 0,02 \\
$\mathrm{~K}_{2} \mathrm{O}(\%)$ & 0,01 & 0,01 & 0,02 \\
$\mathrm{KTK}(\mathrm{Cmol}(+) / \mathrm{kg})$ & 44,42 & 44,16 & 44,89 \\
Kadar air (\%) & 46,39 & 46,23 & 41,09 \\
KB (\%) & 3,37 & 2,86 & 3,69 \\
\hline
\end{tabular}

Sumber : Hasil Analisa Laboratorium Balingtan-Terpadu 


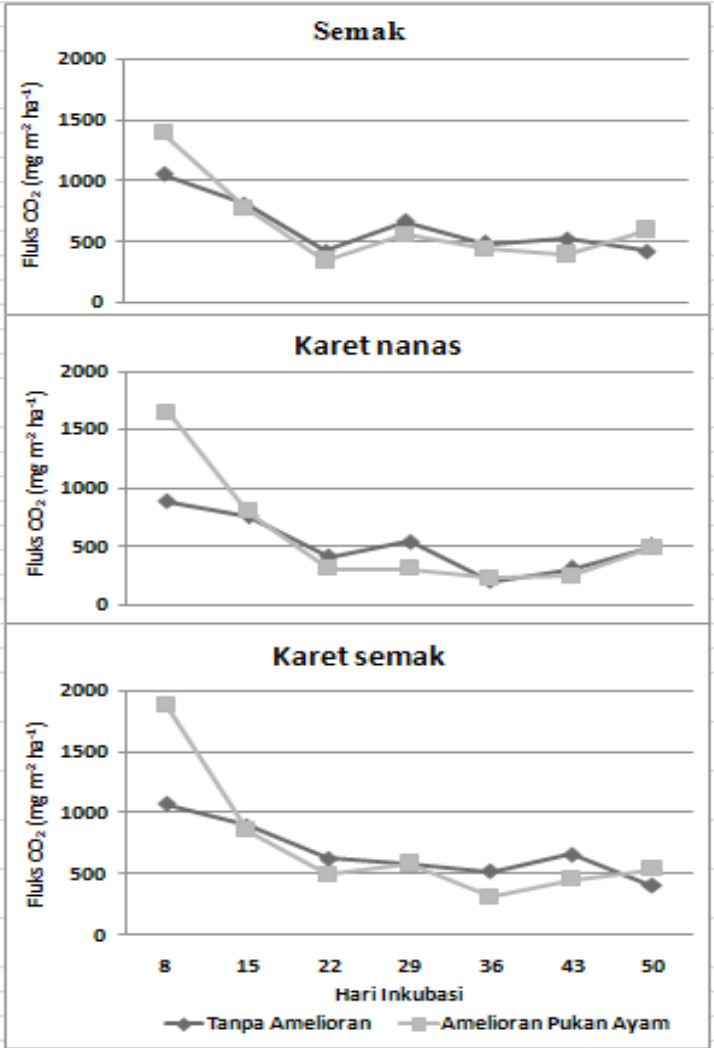

Gambar 2. Fluks $\mathrm{CO}_{2}$ selama proses inkubasi

ayam (A1) pada fase awal inkubasi. Fase awal inkubasi pada hari ke-8 (7 hari setelah pemberian amelioran pupuk kandang ayam), mengalami perombakan dalam jumlah besar dan terdapat perbedaan fluks $\mathrm{CO}_{2}$ yang dihasilkan. Hal ini disebabkan pemberian amelioran pupuk kandang ayam memberikan tambahan bahan organik ke dalam tanah dan meningkatkan aktivitas mikroba tanah sehingga menghasilkan fluks $\mathrm{CO}_{2}$ tertinggi. Selain kandungan bahan organik, peningkatan fluks $\mathrm{CO}_{2}$ dipengaruhi oleh ketersediaan

Tabel 4. Kandungan bahan organik pupuk kandang ayam

\begin{tabular}{c|c}
\hline Parameter & Hasil Pengukuran (\%) \\
\hline C-Organik & 15,62 \\
\hline N-Total & 0,56 \\
\hline P-Total & 0,27 \\
\hline $\mathrm{K}$ & 1,42 \\
\hline $\mathrm{Ca}$ & 0,03 \\
\hline $\mathrm{Mg}$ & 0,04 \\
\hline Kadar Air & 22,22 \\
\hline
\end{tabular}

Sumber : Hasil Analisa Laboratorium Balingtan-Terpdu oksigen pada kondisi aerob di dalam tanah sebagai hasil dari dekomposisi tanah gambut, suhu dan kelembaban tanah [18].

Pemberian amelioran pupuk kandang ayam pada tanah gambut secara nyata meningkatkan jumlah karbon (C) organik tanah. Bahan organik merupakan sumber energi bagi mikroba dalam proses respirasi dalam menghasilkan $\mathrm{CO}_{2}$ [6]. Mikroorganisme tanah berperan penting dalam mempercepat penyediaan hara dan pembentuk sumber bahan organik di dalam tanah [19]. Emisi $\mathrm{CO}_{2}$ terjadi dalam kondisi aerob, dimana mikroorganisme dekomposer seperti bakteri dan jamur dapat beraktivitas secara optimal. Pada kondisi ini produksi gas $\mathrm{CH}_{4}$ pun menjadi terhambat karena $\mathrm{CH}_{4}$ akan teroksidasi oleh bakteri metanotrof menjadi $\mathrm{CO}_{2}[20]$. Kandungan bahan organik yang terdapat pada amelioran pupuk kandang ayam disajikan pada Tabel 4.

\section{Derajat Kemasaman (pH)}

Tanah gambut memiliki $\mathrm{pH}$ yang sangat rendah yaitu antara 3,0-5,0 (Hardjowigeno, 1996) [21]. Tanah gambut dengan kandungan asam organik tinggi sebagian besar bereaksi masam sampai sangat masam dengan $\mathrm{pH}<$ 4 [6]. Kemasaman tanah gambut disebabkan oleh kandungan asam organik tanah dan cepatnya proses dekomposisi bahan organik pada kondisi anaerob menyebabkan terbentuknya

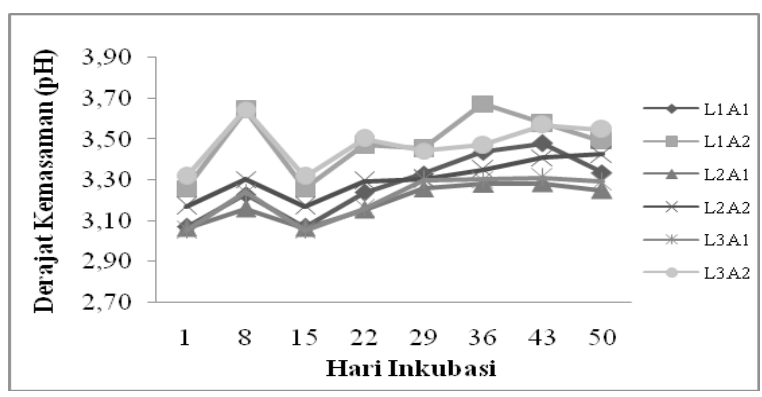

Gambar 3. Perubahan $\mathrm{pH}$ tanah selama inkubasi 
senyawa fenolat dan karboksilat yang menyebabkan tingginya kemasaman gambut dan dapat meracuni tanaman.

Pemberian amelioran pupuk kandang ayam pada awal pengamatan menyebabkan kemasaman tanah gambut meningkat (Gambar 3). Selama periode inkubasi $\mathrm{pH}$ tanah pada seluruh perlakuan memiliki nilai $\mathrm{pH}$ yang terus meningkat, dengan nilai berkisar antara 3,05-3,65 dari awal inkubasi dilakukan. Penambahan unsur hara yang terkandung dalam amelioran pupuk kandang ayam dapat meningkatkan nilai $\mathrm{pH}$ tanah gambut sebesar 0,6 . Peningkatan $\mathrm{pH}$ tanah gambut disebabkan adanya pengolahan lahan seperti lamanya lahan dikelola, pemberian amelioran dan pemupukan serta tingginya permukaan air tanah [16].

\section{SIMPULAN}

Pemberian amelioran pupuk kandang ayam pada penggunaan lahan gambut yang berbeda tidak memberikan pengaruh nyata terhadap penurunan emisi $\mathrm{CO}_{2}$. Penggunaan tanah gambut yang berasal dari penggunaan lahan yang berbeda memberikan pengaruh nyata terhadap emisi $\mathrm{CO}_{2}$ dengan rata-rata emisi $\mathrm{CO}_{2}$ tertinggi pada tanah gambut dengan tanaman karet semak dan pemberian amelioran pupuk kandang ayam $4 \mathrm{t} / \mathrm{ha}$, sedangkan rata-rata emisi $\mathrm{CO}_{2}$ terendah dihasilkan pada tanah gambut dengan tanaman karet dan tanaman sela nanas tanpa pemberian amelioran pupuk kandang ayam.

\section{UCAPAN TERIMA KASIH}

Penulis mengucapkan terima kasih kepada segenap tim peneliti dan teknisi Laboratorium Gas Rumah Kaca Balai Penelitian Lingkungan
Pertanian yaitu Ali Pramono, Titi Sopiawati, Sri Wahyuni, Jumari, Susanto dan Jumari B atas kerjasama dan bantuan dalam pelaksanaan penelitian.

\section{DAFTAR PUSTAKA}

(1) Sri Ratmini NP. Karakteristik dan pengelolaan lahan gambut untuk pengembangan pertanian. Jurnal Lahan Suboptimal. 2012 Oktober; 1(2): 197-206.

(2) Hooijer A, S Page, JG Canadell, M Silvius, J Kwadijk, H Wosten, and J Jauhiainen. 2010. Current and future $\mathrm{CO}_{2}$ emissions from drained peatlands in Southeast Asia. Biogeosciences. 2010 March; 7: 1505-1514.

(3) World Wide Fund for Nature (WWF). Deforestation, Forest Degradation, Biodiversity Loss and $\mathrm{CO}_{2}$ Emision in Riau, Sumatera, Indonesia: One Indonesian Propinve's Forest and Peat Soil Carbon Loss Over a Quarter Century and It's Plans for the Future. WWF Indonesia Tecnical Report. www.wwf.or.id; 2008.

(4) Langeveld CA, R Segers, BOM Dirks, A Van den Pol-van Dasselar, GL Velthof dan A Hensen. Emissions of $\mathrm{CO}_{2}, \mathrm{CH}_{4}$, and $\mathrm{N}_{2} \mathrm{O}$ from pasture on drained peat soils in the Netherlands. European Journal of Agronomy. 1997 September; 7: 35-47.

(5) Hooijer A, M Silvius, H Wosten and $S$ Page. PEAT- $\mathrm{CO}_{2}$, Assessment of $\mathrm{CO}_{2}$ emissions from drained peatlands in SE Asia, Delft Hydraulics report Q3943; 2006.

(6) Intergovernmental Panel on Climate Change (IPCC). Climate Change 2001. The Scientific basis. Contribution of Working Group 1 to the Third Assessment Report of the 
Intergovernmental Panel on Climate Change. Houghton, J.T., Ding, Y., Griggs, D.J., Noguer, M., van der linden, P.J., Xiaosu, D. Cambridge: Cambridge University Press; 2001.

(7) Mauna Loa Observatory/NOAA. www. $\mathrm{CO}_{2}$ Now.org. Atmospheric $\mathrm{CO}_{2}$. Diakses pada tanggal 22 Agustus 2016.

(8) Barchia MF. Gambut. Agroekosistem dan Transformasi Karbon. Yogyakarta: Gadjah Mada University Press; 2006.

(9) Koesrini dan Eddy William, 2006. Pengaruh pemberian bahan amelioran terhadap pertumbuhan dan hasil cabai merah (Capsicum annum L.) di lahan sulfat masam. Buletin Agronomi. 2006 Oktober; 34(3): 153-159.

(10) Firmansyah MA dan MS Mokhtar. Profil ICCTF di Kalimantan Tengah: Pengolahan Lahan Gambut Berkelanjutan. Kalimantan Tengah: Balai Pengkajian Teknologi Pertanian Kalimantan Tengah; 2012.

(11) Setyanto P. Methane Emission and Its Mitigation in Rice Fields Under Different Management Practices in Central Java. Doctor of Philosophy. Malaysia: Universiti Putra Malaysia; 2004. P. 3.1-3.25.

(12) Khalil MAK, RA Rasmussen, MX Wang and L Ren. Methane emission from rice fields in China. Environment Science Technology. 1991 May; 25: 979-981.

(13) Irawan A dan T June. Hubungan iklim mikro dan bahan organik tanah dengan emisi $\mathrm{CO}_{2}$ dari pembukaan tanah di hutan alam Babahaleka Taman Nasional Lore Lindu, Sulawesi Tengah. Jurnal Agricultural Meterologi. 2011 Mei; 25(1): 1-8.
(14) Salampak, Sustiyah, dan V Amelia. Fluks gas karbondioksida pada tanah gambut pedalaman di Kalampangan, Kalimantan Tengah. Jurnal Agri Peat. 2014 Maret; 15(1): 24-33.

(15) Maswar, O Haridjaja, S Sabiham, dan MV Noordwijk. Cadangan, kehilangan, dan akumulasi karbon pada perkebunan kelapa sawit di lahan gambut tropika. Journal of Soil and Land Utilization Management. 2011; 8(1): 1-10.

(16) Rumbang N, B Radjagukguk dan D Prajitno. Emisi carbon dioksida $\left(\mathrm{CO}_{2}\right)$ dari beberapa tipe penggunaan lahan gambut di Kalimantan. Jurnal Ilmu Tanah dan Lingkungan. 2009; 9(2): 95-102.

(17) Nusantara RW, Sudarmadji, TS Djohan dan E Haryono. Emisi CO2 tanah akibat alih fungsi lahan hutan rawa gambut di Kalimantan Barat. Jurnal Manusia dan Lingkungan. 2014 November; 21(3): 268-276.

(18) Kechavarzi C, Q Dawson, PB LeedsHarrison, J SzatyLowicz, and T. Gnatowski. Water-table management in lowland UK peat soils and its potential impact on $\mathrm{CO}_{2}$ emission. Soil Use Management. 2007 September; 23: 359-367.

(19) Pelczar MJ and ECS Chan. Elements of Microbiology. Alih bahasa : Hadioetomo, dkk. Jakarta: Penerbit Universitas Indonesia; 2005.

(20) Setyanto P. Perlu Inovasi Teknologi Mengurangi Emisi Gas Rumah Kaca dari Lahan Pertanian. Balingtan. Badan Litbang Pertanian, Kementerian Pertanian. Sinar Tani 23-29 April 2008.

(21) Hardjowigeno HS. Ilmu Tanah. Akademika Pressindo: Jakarta; 2002. 